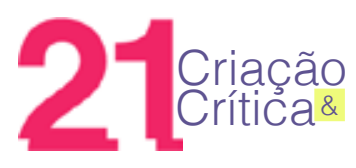

\title{
Arte, tRagédia e INTERDição da CRITICIDADE o confronto entre ética e estética em "Estão apenas ensaiando", de Bernardo Carvalho
}

\author{
Márcio Felipe da Silva ${ }^{1}$ \\ Vinícius Carvalho Pereira ${ }^{2}$
}

\begin{abstract}
Resumo: Em certas circunstâncias, tomar a escrita de ficção como uma dimensão outra do real parece equivaler à suposição de que a maravilha de um truque de mágica está não na engenhosidade técnica através da qual nossos sentidos são ludibriados, mas na ideia de que, por um instante, as leis da física foram de fato suspensas e uma pessoa levitou ou dois corpos ocuparam o mesmo lugar a um só tempo. À luz das considerações de Ortega y Gasset sobre a autonomia do objeto artístico em relação à realidade da qual, ao tratar da arte, o público em geral não consegue prescindir, o conto "Estão apenas ensaiando", de Bernardo Carvalho, revela-se - tanto por seu conteúdo quanto por sua expressão - pródigo em possibilidades de leitura que ressaltam o embate entre ética e estética. Assim, o raciocínio alegórico de Gasset e os questionamentos ético-narrativos presentes em textos de Adorno e de Brecht são aplicados, nesta análise do conto de Carvalho, a fim de evidenciar como a ordem cronológica entre o evento catastrófico e o objeto artístico que com ele guarde alguma semelhança tem pouca importância no modo como a interdição do discurso estético se opera.
\end{abstract}

Palavras-Chave: Ética; Estética; Mímesis; Representação; Arte.

\section{ETHICS AND AESTHETICS IN "ESTÃO APENAS ENSAIANDO", BY BERNARDO CARVALHO}

ABSTRACT: In certain circumstances, seeing fictional writing as another dimension of reality seems to be equivalent to supposing that the wonder of a magic trick did not lie in the technical ingeniousness by which our senses are deceived, but in the idea that, for an instant, the laws of Physics were really suspended and a person levitated, or two bodies occupied the same space simultaneously. In the light of Ortega y Gasset's considerations about the autonomy of the artistic object in relation to the reality the general public cannot do without when dealing with art, the short story "Estão apenas ensaiando", by Bernardo Carvalho, is abundant with reading possibilities that highlight a clash between ethics and aesthetics, due to both its content and its expression. Therefore, in this analysis of Carvalho's short story, we apply Gasset's allegory and Adorno's and Brecht's ethical and narrative reflections in order to show how the chronological order between a catastrophic event and an artistic object that bears resemblance to it are little important in the interdiction of the aesthetic discourse.

KeYwods: Ethics; Aesthetics; Mimesis; Representation; Art.

Em seu clássico ensaio "A desumanização da arte”, Ortega y Gasset (2001) recorre a uma série de metáforas visuais com o objetivo de dissociar os procedimentos de apreciação que tomam a obra de arte em termos de representação da realidade (concreta e abstrata) daqueles que conduziriam a uma avaliação apropriada do objeto artístico, fundados na dimensão formal e estética dos mecanismos de que o artista se utilizou para produzi-lo. Ao analisar o modo como a maioria das pessoas se relacionam com a arte, interessadas sobretudo pela natureza realista das paisagens, dos dramas e dos destinos humanos nela retratados, Gasset constata a existência de um paradoxo, uma vez que o apego ao caráter representacional dessas produções vai de encontro ao truísmo segundo o qual a virtualidade é condição sine qua non para que uma obra de arte possa ser assim considerada, de modo que: "o objeto artístico só é artístico na medida em que não é real" (ORTEGA Y GASSET, 2001, p. 27).

Neste sentido, o autor propõe uma cena na qual figuram quatro personagens - uma mulher, um médico, um fotógrafo e um pintor - que testemunham a agonia de um "homem ilustre" no leito

1 Mestrando no Programa de Pós-Graduação em Estudos de Linguagem da Universidade Federal de Mato Grosso - felipeholloway2@gmail.com.

2 Doutor. Professor do Departamento de Letras e do Programa de Pós-Graduação em Estudos de Linguagem da Universidade Federal de Mato Grosso - viniciuscarpe@gmail.com. 


\section{1}

de morte. Segundo Gasset, a liberdade de que cada testemunha dispõe, neste arranjo, para representar o cenário observado, é diretamente proporcional ao nível de distanciamento afetivo e/ ou moral guardado em relação ao infortúnio do moribundo. Dessa forma, na mulher e esposa do enfermo, tal afastamento praticamente inexiste, já que ela se encontra enredada no turbilhão de emoções suscitadas pelo sofrimento do companheiro. Embora mais distantes sentimentalmente, o médico e o jornalista estão, por sua vez, comprometidos com questões éticas relativas a suas profissões, que os obrigam, respectivamente, a interferir no acontecimento e a nele não se envolver. Resta, portanto, o pintor, cujas indiferença emocional quanto à cena presenciada e isenção moral inerente a seu ofício o fariam apto a representar pictoricamente o panorama desolador, preocupando-se apenas com pormenores de natureza estética, como as cores e a incidência da luz. A distância alcança no artista sua maior extensão.

Tematizando situação análoga à da metáfora do filósofo espanhol, ao mesmo tempo em que complexifica as questões por ela suscitadas devido à inserção de elementos de estrutura e enredo que impactam sobremaneira as relações entre ética e estética, o conto "Estão apenas ensaiando", do escritor Bernardo Carvalho (2000), possibilita uma compreensão ainda mais ampla tanto do que, de acordo com os estudos literários das correntes pós-estruturalistas (cujas ideias, em certa medida, o ensaio do próprio Gasset preconiza), constituiria uma análise adequada do objeto artístico quanto das ocasiões em que tal análise se mostra impossível de ser efetivada.

Neste artigo, procuramos investigar as camadas por meio das quais faz-se possível entrever, na tessitura do conto de Bernardo Carvalho, o reforço à noção de que arte e realidade configuram instâncias apartadas e autônomas, cujas fronteiras, uma vez borradas, interditam a concretização de uma análise que confira protagonismo a fatores de ordem estética.

\section{Realidade e representação}

Originalmente publicado em 2000, na coletânea Catástrofe e representação, organizada por Arthur Nestrovski e Márcio Seligmann-Silva, o conto "Estão apenas ensaiando", de Bernardo Carvalho, transcorre no interior de um teatro onde acontece o ensaio de uma peça. Enquanto dois atores reencenam exaustivamente um trecho do texto-base, um homem entra no teatro e se aproxima aos poucos do diretor do espetáculo e de sua assistente, sentados na plateia, durante as interrupções do ensaio. Aproveitando-se dessas mesmas pausas para instruções ao elenco, um dos técnicos responsáveis pela iluminação do palco conta a seu colega, no mezanino, uma piada a cujo final ele tem dificuldade para chegar, dadas as sucessivas retomadas da cena. Há uma divergência entre o diretor e o ator principal (que também demonstra preocupação pelo atraso de sua esposa, cuja vinda ao teatro é esperada) quanto ao modo como a fala de um personagem camponês deve ser enunciada. Em meio a repetições de gestos, frases e ações, por parte dos personagens e do próprio narrador, o conto se desenvolve num crescendo aflitivo que culmina com a chegada do desconhecido ao lado do diretor e da assistente, aos quais, então, ele sussurra algo. Neste momento, simultaneamente, o ator compreende a mensagem trazida pelo homem (informação que, implicando a morte inesperada de sua esposa, coloca o próprio ator em situação similar à do personagem interpretado) e os técnicos no mezanino riem da piada a cujo desfecho foi finalmente possível chegar.

Embora o conto não trate especificamente do fazer literário, é possível enquadrá-lo na categoria de metaficção, de acordo com a definição de Linda Hutcheon (1984), para quem o termo 


\section{1}

abrange aquilo que se constitui como "ficção a respeito de ficção, isto é, ficção que inclui nela mesma um comentário sobre sua própria narrativa e/ou sobre sua identidade linguística" (HUTCHEON, 1984 apud MOISÉS, 2013, p. 290). Neste sentido, evoca-se ainda a concepção de Massaud Moisés (2013), que define a metaficção como:

[...] a ficção que pensa a si própria dentro do texto em que se desenvolve, obedecendo a um impulso de autodesvendamento, como se o autor, desdobrado num 'outro', se espionasse no ato de construir o edifício narrativo. (MOISÉS, 2013, p. 290)

Tem-se, assim, uma obra que, ao descrever a preparação para uma peça de teatro, a arte da representação, aborda problemas que também se mostram caros à literatura e, por extensão, aos estudos literários, como a questão da verossimilhança, o realismo e a arte como representação da realidade. No entanto, o conto não se limita a remeter a esses tópicos no plano da "forma do conteúdo", para usar a terminologia linguística proposta por Louis Hjelmslev (2006), mas também no da "forma da expressão". Isto porque tanto as ideias manifestadas pelos personagens acerca do modo como a arte deve reformular a realidade quanto o evento trágico que se superpõe ao texto da peça ensaiada, impedindo que sobre este seja possível tecer, por parte dos personagens, uma análise de caráter estritamente esteticista, são complementados pela própria estrutura do texto, cujas repetições podem constituir em si mesmas um método que visa à educação dos sentidos para a apreciação do verdadeiro objeto artístico.

\section{Dos espaços conspurcados: entre a autonomia e a imitação}

"Estão apenas ensaiando" nasce de uma ruptura a princípio sutil: o "teatro" e a "rua", aqui empregados como epítomes simbólicos da arte e da realidade, do "simulacro" e da "vida", têm transgredida a fronteira que mutuamente os isola, dando início a um processo que aos poucos os confunde, impondo sobre a representação o peso aniquilador do real. O espaço artístico, escuro e silencioso do teatro é invadido por sons e luzes da rua, que infiltram ali um representante sombrio - o desconhecido portador da notícia catastrófica -, cuja aproximação gradativa do palco onde o ensaio se desenrola corresponde à diminuição da distância obrigatória a ser guardada entre o mundo e a arte.

[...] o homem que acabou de entrar ao fundo é ainda menos que um vulto sem rosto, porque já não tem nem mesmo a nesga de luz das cinco para destacá-lo da penumbra, agora que a porta que separa a sala escura do hall e da rua se fechou. (CARVALHO apud MORICONI, 2000, p. 592)

É interessante notar a inversão que aqui se promove em termos de caracterização: o mensageiro que adentra o espaço da arte é apresentado em tons soturnos, de maneira algo estereotipada, que emula $\mathrm{o}$ arquétipo com que a arte ocidental tem representado a morte personificada ao longo da História; no entanto, o caráter preliminar da encenação faz com que o ator responsável por interpretar a Morte no palco não esteja usando "a foice ou o manto" que Ihe são característicos. De forma similar, 


\section{1 cricáa}

enquanto à personagem Morte não é dado manifestar-se oralmente, visto que o diretor sempre interrompe o ensaio antes de sua fala, é justamente a mensagem sussurrada pelo homem envolto em sombras a responsável pelo desfecho trágico do conto, quando o ator principal compreende, pelas reações da assistente e do diretor à notícia, que sua mulher foi atropelada a caminho do teatro.

Aponta-se, então, para o primeiro indício de uma intersecção entre os planos da representação e da realidade, cujo enviado se apropria de uma caracterização arquetípica do âmbito das artes e possui, para o ator, função similar à que a figura mitológica exerce sobre o personagem interpretado no palco. A personificação da morte, responsável por privar o homem da amada, se mostra passiva, reduzida momentaneamente à condição de figurante, no trecho da peça que nos é dado acompanhar; a figura que traz a notícia catastrófica, por sua vez, age, e é em torno da expectativa por sua ação que a narrativa se move, bem como é consequência dessa ação a paralisia da arte e do discurso que a tem por objeto.

A dissensão entre o ator principal e o diretor do espetáculo constitui o mais importante ponto de reflexão teórica do conto no plano da forma do conteúdo, e o principal responsável por permitir o enquadramento da narrativa nas definições de "metaficção" propostas por Hutcheon e por Moisés:

O diretor repete irritado que falta vigor à interpretação do ator, e desespero, não parece que o humilde lavrador esteja realmente sofrendo ou indignado pela injustiça da morte da mulher na flor da idade. [...] [o ator] Desanca o diretor, diz que não dá para mostrar desespero com um texto daqueles, inverossímil, ninguém vai falar com a morte daquele jeito depois de perder a mulher de uma maneira violenta. Resmunga baixinho qualquer coisa sobre o tipo de representação que aquela cena exige, na sua opinião, e que tem a ver com um certo distanciamento. (CARVALHO apud MORICONI, 2000 p. 593)

Voltados para o contexto de uma peça teatral, condensam-se aqui dois dos procedimentos mais comuns e contrastantes de concepção do objeto artístico. É possível identificar o primeiro deles no discurso do diretor, que, mais adiante, reforça suas convicções ao instruir o ator sobre o modo como este deve interpretar determinado personagem:

Será que você não compreende? Ele perdeu a mulher, na flor da idade, está desesperado, indignado contra a injustiça da morte e dos homens e por isso a invoca, ainda acredita que pode convencê-la a lhe devolver a mulher adorada. Ninguém diz isso com distanciamento. (CARVALHO apud MORICONI, 2000, p. 594)

Ao açodar o ator a imprimir "vigor" e "desespero" à sua performance, sob pena de não conseguir transmitir ao espectador o sofrimento ou a indignação do personagem pela morte precoce da esposa, o diretor considera a arte em sua dimensão de representação de um "real possível" - toma-a como "mimese", enfim. Objeto de intensa discussão desde suas primeiras menções conhecidas, por volta do século IV a.C., o conceito de mimese tem se estabilizado em torno da noção de "imitação", já que, de acordo com Lucas (1990), os demais termos a ele associados também se referem à ideia de "fazer ou criar alguma coisa que se assemelha a qualquer outra coisa" (apud MOISÉS, 2013, p. 301). Nos diálogos da República de Platão, confere-se à imitação promovida pela arte, bem 


\section{1}

como ao ofício do artista, um caráter metafisicamente pejorativo: a cama representada num quadro seria um simulacro de uma cama tangível, que não passaria, por sua vez, de uma versão imperfeita da cama ideal, arquetípica. Estando, portanto, "afastada três graus da natureza" (PLATÃO, 2000, p. 429), a representação do real tenderia a distanciar quem nela se detém da verdade.

A Poética de Aristóteles de certo modo reabilita a mimese, resgatando-a do cenário de competição com o conhecimento epistêmico em que Platão a situava. Apesar de também não restringir o objeto de análise às artes fundadas na linguagem verbal (seu foco se estende ainda à pintura, à música, à escultura e à dança), Aristóteles fornece os parâmetros conceituais que nortearão os estudos literários pelos séculos seguintes. De fato, talvez seja justamente a importância canônica da Poética para a teoria literária que impediu as correntes modernas de desprezarem-na, conquanto tenham constantemente reivindicado para a literatura uma independência em relação ao mundo tangível, como veremos a seguir. É preciso salientar, no entanto, como sugere Compagnon (1998), certa desnaturalização moderna da concepção aristotélica da mimese, que sofreu sutis distorções, deixando de remeter ao "que poderia ter acontecido, o possível, segundo a verossimilhança" para se relacionar com a noção mais superficial de referencialidade. Segundo James Wood (2008),

[na abordagem aristotélica,] a ideia importante é a plausibilidade hipotética - a probabilidade: a probabilidade envolve a defesa da imaginação crível contra o incrível. Decerto é por isso que Aristóteles escreve que uma impossibilidade convincente na mimese é sempre preferível a uma possibilidade inconvincente. O peso recai não sobre [...] a referência (visto que Aristóteles reconhece que um artista pode representar algo que é fisicamente impossível), e sim sobre a persuasão mimética: a tarefa do artista é nos convencer de que aquilo poderia ter acontecido. Assim, a plausibilidade e a coerência interna se tornam mais importantes do que a exatidão referencial. E essa tarefa [...] demandará um grande artifício ficcional, e não um mero registro informativo. (WOOD, p. 191-192)

A crítica moderna opõe à interpretação que ela própria realiza acerca dos postulados de Aristóteles sobre a mimese a ideia de uma literatura autorreferencial. Na esteira dos estudos linguísticos de Ferdinand de Saussure e dos semióticos de Charles Pierce, para os quais não se faz relevante o mundo tangível, exterior à linguagem, declara-se a "autonomia da literatura em relação à realidade, ao referente, ao mundo, [e defende-se] a tese do primado da forma sobre o fundo, da expressão sobre o conteúdo, do significante sobre o significado" (COMPAGNON, 2001, p. 97). Quando o ator principal de "Estão apenas ensaiando" atribui à cena da peça o caráter de inverossímil, além de julgar que seja a interpretação distanciada a mais adequada para a fala do personagem, é possível que esteja se referindo a um procedimento que, como as correntes modernas que veem na autorreferencialidade uma característica inerente à literatura, não manifesta interesse pelo "exterior referencial da linguagem" (ou, neste caso, da representação teatral), na expressão que Compagnon (2001, p. 52) recupera de Derrida. Sugere-nos o ator que o distanciamento emocional com que a fala deve ser pronunciada provém de uma demanda do texto da peça, que, ao soar refratário a qualquer pretensão realista, uma vez que Ihe falta verossimilhança, exige do artista uma postura que deixe evidente sua condição de artifício, de quimera. 


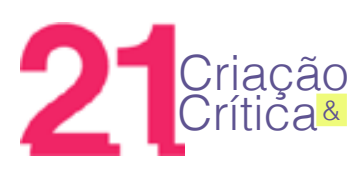

A divergência tematizada no conto encontra paralelo curioso num caso real a que Iser (2002) faz referência no ensaio "Os atos de fingir ou o que é fictício no texto ficcional". Consta que o dramaturgo suíço Friedrich Dürrenmatt teria se mostrado insatisfeito com a montagem que o italiano Giorgio Strehler fizera de sua famosa peça, $A$ visita da velha senhora (Der Besuch der alten Dame, 1956). A origem do desagrado estava no fato de Strehler ter revestido a encenação do texto original com elementos que não apenas neste não estavam presentes como destituíam-no, segundo o autor, de seu tom autoconsciente ou metaficcional.

Desta maneira, diz Dürrenmatt, surgiu na peça um realismo que tinha de destruí-la. Pois o autor incorporara em seu drama uma série de alusões, que deveriam dar ao público a sensação constante de tratar-se de uma peça de teatro. Noutras palavras, a própria peça fora feita com sinais ficcionais para que apresentasse o mundo representado ao mesmo tempo no modo do como se. No momento, porém, que a direção suprimiu os sinais ficcionais e assim eliminou o como se, tornou-a representação de uma realidade determinada e verificável no mundo empírico dos espectadores. Como, na encenação, a peça se transformara na designação de tal realidade, a dimensão remissiva se esvaziara. (ISER, 2002, p. 975-976)

Embora haja no conto de Bernardo Carvalho mais menções ao método de representação mimético defendido pelo diretor, é possível pensar que a opção pelo teatro como a modalidade artística aqui tematizada se mostre mais propensa a corroborar a concepção esteticista do personagem ator, segundo a qual a arte deveria manter evidentes os elementos que denunciam sua dimensão de artifício. Afinal, conquanto dê origem ao romance (WOOD, 2008, p. 119), gênero literário que gestará, no século XIX, o movimento do Realismo, a arte da representação é, por excelência, o espaço do artifício autoconsciente. Em seu formato clássico, o espetáculo teatral impõe limitações e demanda contratos firmados entre atores e plateia (expedientes por natureza refratários a aspirações realistas), como a convenção da quarta parede e o uso do solilóquio como recurso expositivo de motivações e pensamentos que, de outro modo, estariam ocultos do público que assiste à peça. No conto, a reiteração das recomendações do diretor e a escolha do espaço narrativo tenderiam, então, a criar um equilíbrio de forças entre ambas as concepções das quais o narrador parece manter equidistância -, que também se igualarão na paralisia diante do evento catastrófico que se superpõe ao texto ensaiado no desfecho da narrativa.

Com a exposição dos polos opostos em que os personagens se situam quanto ao método que melhor convém à execução formal da peça, "Estão apenas ensaiando" fornece um breve panorama da noção dicotômica que se manteve na base das discussões sobre o objeto da arte, que ora tratava do mundo, ora referia-se a si mesma. Além disso, a contaminação do espaço artístico por um elemento da realidade externa sobre o qual incide uma caracterização estetizante pelo narrador confunde os limites do real e da representação, de modo a preparar o caminho para a inserção do componente ético que condenará à imobilidade quaisquer juízos fundados na dimensão não-referencial da arte encenada. 


\section{1)}

\section{$3 \mathrm{~A}$ arte e a tragédia pretérita}

Dois fatores contribuíram de maneira decisiva para que o século $X X$ se convertesse no campo historicamente mais fértil para a abordagem do problema ético da representação artística de tragédias reais: a ocorrência de duas grandes guerras e o fato de que, pela primeira vez, houve registros visuais de um conflito bélico em larga escala. A importância do lastro legado à posteridade por meio de fotos e vídeos dos embates, bem como de seus efeitos devastadores, se dá no sentido de que a experiência da guerra se tornou menos abstrata para aqueles que nela não se engajaram diretamente, aflorando no senso comum uma sensibilidade reativa a tentativas de apropriação, com fins artísticos, da memória coletiva desses eventos históricos - tentativas nas quais era comum enxergar-se uma forma de desrespeito às vítimas e a suas famílias, além de certo ranço de parasitismo.

Neste sentido, o massacre do Holocausto assoma, imenso, como o acontecimento que mais acirrou o debate em torno da moralidade da representação, com fins estéticos, da barbárie. A tese da interdição do discurso artístico - mais especificamente o literário - diante da catástrofe foi formulada por Bertolt Brecht (1948). Referindo-se a alguns dos locais em que a mortandade perpetrada pelas forças nazistas se fez sentir com mais intensidade, o dramaturgo alemão postula que

Os acontecimentos em Auschwitz, no gueto de Varsóvia e em Buchenwald não admitem, indubitavelmente, descrição alguma, em nenhuma forma literária. $\mathrm{Na}$ verdade, a literatura não está preparada para tais acontecimentos, mas não desenvolveu nenhum meio para eles. (BRECHT, 1948 apud PIGLIA, 2011)

Ao analisar o posicionamento de Brecht, o escritor argentino Ricardo Piglia nota que o impedimento ao ofício do artista diante do Holocausto não se dá, segundo o autor alemão, como um imperativo moral de duração indeterminada, uma vez que Brecht "apenas se refere às dificuldades técnicas que fundam as relações entre experiência e informação" (PIGLIA, 2011). A abrangência de um evento como a guerra impede que sobre ela o artista possa ter compreensão similar à que guarda em relação ao universo ficcional que ele próprio arquiteta, por exemplo. Em uma nota de seu Diário de Trabalho, Brecht (1940 apud PIGLIA, 2011) lamenta não entender da guerra então em curso tanto quanto gostaria, ao passo que, da obra que redigia naquele momento, a peça $S$ r. Puntila, sua consciência é quase total:

De Puntila não me importa quase nada; da guerra, tudo; sobre Puntila posso escrever quase tudo; sobre a guerra, nada. Não quero dizer 'não me é lícito', quero propriamente dizer 'no sono in grado', não sou capaz. É interessante ver até que ponto a literatura, como atividade, como prática, está longe dos centros em que se desenrolam os acontecimentos dos quais tudo depende [...] (BRECHT, 1940 apud PIGLIA, 2011, grifos nossos)

Trata-se, portanto, de uma postura em essência diversa da que, mais tarde, manifestaria Theodor Adorno (2002) no famoso ensaio "Crítica cultural e sociedade", no qual, dado o contexto histórico de sua publicação, o teórico escreve o célebre trecho que equipara simbolicamente o ato da escrita literária a outro, de barbárie: 


\section{1}

A crítica cultural encontra-se diante do último estágio da dialética entre cultura e barbárie: escrever um poema após Auschwitz é um ato bárbaro, e isso corrói até mesmo o conhecimento de por que hoje se tornou impossível escrever poemas. (ADORNO, 2002, p. 61)

Embora mais tarde Adorno classifique melhor suas colocações, afirmando que "o sofrimento [...] também exige a existência continuada da arte que ele proíbe" (1997, apud RICHARDSON, 2000, tradução nossa), sua menção ao impedimento do discurso artístico parte menos de adversidades de ordem técnica que de uma problemática de cunho ético. Seu questionamento maior, como sugere Anna Richardson no artigo "The Ethical Limitations of Holocaust Literary Representation" (2005), parece mesmo ser "como [...] alguém pode pretender representar algo tão extremo como o Holocausto, quando em teoria não é possível fazê-lo sem de certa forma validar a cultura que o produziu?" (2005, tradução nossa). Adorno preocupa-se, pois, com a ética que subjaz à suposição de que seja possível extrair prazer estético (já que a arte lida com a categoria do belo) da barbárie, e conjectura sobre a representação como chancela para (ou condescendência com) o horror:

Quando até mesmo o genocídio se torna propriedade cultural na literatura comprometida, torna-se mais fácil seguir complacente com a cultura que engendrou o assassínio (ADORNO, 1997 apud RICHARDSON, 2005, p. 1, tradução nossa)

Têm-se aqui duas das mais recorrentes perspectivas de análise do confronto entre ética e estética no contexto da arte que tematiza (ou guarda semelhanças inegáveis com) uma tragédia do plano extraficcional. De um lado, a paralisia do discurso artístico se dá pela dimensão inenarrável do evento catastrófico, fundada na impossibilidade técnica de abranger tal evento da mesma maneira que se consegue dar conta do arco narrativo de uma obra comum, com a qual o real não compartilha vínculos de natureza estritamente referencial; de outro, a interdição se baseia na impossibilidade ética de extrair um prazer estético da tragédia sem que, nesse procedimento, o artista se torne condescendente com o contexto que tornou a própria tragédia possível. Embora a narrativa de "Estão apenas ensaiando" inverta a cronologia entre a catástrofe e a representação, tirando da equação o elemento de causalidade e substituindo-o pelo de casualidade, é interessante perceber como os critérios para a interdição do discurso esteticista (que, como veremos a seguir, parte tanto do personagem ator quanto do diretor) permanecem rigorosamente os mesmos.

\section{$4 \mathrm{~A}$ arte e a tragédia por vir}

Uma análise superficial do conto de Bernardo Carvalho pode facilmente induzir a uma leitura limitada e limitante quanto ao que se concretiza em seu desfecho. Isto porque as constantes interrupções do ato encenado e as sucessivas repetições da frase que constitui o título do conto (que talvez conduzam o leitor a pensar na preparação para um clímax em que o ensaio deixa finalmente de sê-lo e se converte na arte representacional acabada) criam, em face da superposição do real ao texto da peça, um ambiente aparentemente propício a uma interpretação no seguinte sentido: o discurso artístico só pode ser idealmente efetivado quando as fronteiras entre experiência e representação são apagadas. Essa interpretação tiraria parte significativa de seu lastro do trecho que se segue: 


\section{1 chicáa}

E ao ver o homem que sussurra ao ouvido do diretor, e o olhar deste e de sua assistente, que pela primeira vez não o interrompem, mas permanecem a encará-lo com os olhos aterrados e arregalados (a assistente com os olhos cheios de lágrimas diante da súplica que o lavrador faz à morte) [...], embora a entonação no palco tenha sido a mesma e devesse portanto, pela lógica, ser mais uma vez interrompida, o próprio ator interrompe a ação e por fim compreende [...] o que sente o humilde lavrador; compreende por que o diretor não o interrompeu desta vez, porque por fim esteve perfeito na pele do lavrador em sua súplica diante da morte; compreende que por um instante encarnou de fato o lavrador, que involuntária e inconscientemente, por uma trapaça do destino, tornou-se o próprio lavrador pelo que aquele vulto veio anunciar. (CARVALHO apud MORICONI, 2000, p. 594, grifos nossos)

O equívoco da suposição ocorre por desconsiderar-se certa possibilidade de causa para a não interrupção, por parte do diretor, da cena ensaiada no palco, e por atribuir-se sentido positivo, do ponto de vista artístico, ao trecho "tornou-se o próprio lavrador". Assim, da mesma forma como, de acordo com Ortega y Gasset, a população em geral tende a comportar-se de modo passional ante o objeto artístico, avaliando-o pela humanidade ou realismo das histórias e paisagens nele retratados, comovendo-se com os destinos dos personagens etc., há uma propensão ao entendimento de que, para soar convincente, o artista precisa desfazer-se de sua própria consciência e sero ente imaginário sobre o qual fabula ou cujas ações interpreta. Esquece-se de que, como escrevem Ducrot e Todorov (1977 apud BRAITH, 1987, p. 10-11), "o problema da personagem é antes de tudo linguístico, que não existe fora das palavras, que a personagem é um 'ser de papel'” cuja incompletude fenomenológica, portanto, faz-se impossível a uma consciência real, completa como a do artista, encarnar.

Dadas as possibilidades mais comuns de uma avaliação inconsistente, cumpre investigar de modo mais arguto o que se encontra implicado na cena que constitui o clímax do conto, desvelandose, assim, certo movimento narrativo que vai de encontro às hipóteses de leitura acima aventadas.

A princípio, é preciso destacar das reações do diretor e do ator aquilo que têm de equivalente: a paralisia das funções que vinham desempenhando no instante em que lhes chega a notícia sobre o mundo exterior. Para o primeiro personagem, esta função é a própria avaliação crítica da performance do ator; este, por seu turno, tem cessada sua função de intérprete do camponês enlutado. A suspensão dos papéis do diretor e do ator surge descrita, respectivamente, nos seguintes excertos: "o diretor não o interrompe [...], [pois ele e sua assistente] permanecem a encará-lo com os olhos aterrados e arregalados"; e "o próprio ator interrompe a ação". A repetição do verbo "interromper" (que, em favor da eliminação estética de um eco, poderia ter sido preterido por um sinônimo) num curto espaço de texto parece indicar a natureza semelhante desses dois procedimentos de suspensão. De fato, o que os distingue aqui é um traço sutil, relacionado ao lugar que os personagens ocupam dentro da dinâmica da representação. Poder-se-ia dizer que, se ambos têm sua performance interrompida no ensaio, o elemento disruptivo é diferente para o diretor e para o ator.

Retomemos, pois, "A desumanização da arte", de Ortega y Gasset. Numa de suas passagens mais famosas, o filósofo espanhol propõe a observação hipotética de um jardim situado além do vidro de uma janela. Aquele cujo foco da visão se detém na paisagem não verá o vidro. No entanto, se o foco for reajustado para a barreira transparente entre o observador e o jardim, este não passará de uma massa indistinta de cores. Os dois procedimentos de fixação do olhar são 


\section{1}

autoexcludentes. Tomando a observação objetiva do jardim como a apreciação que considera apenas os panoramas "humanos" ou "realistas" da obra de arte, e o enfoque no vidro como a análise das virtualidades que constituem o objeto artístico como mediação estética, Gasset (2001, p. 27) conclui que "quem na obra de arte procura comover-se com os destinos de João e Maria ou de Tristão e Isolda e neles acomoda a sua percepção espiritual, não verá a obra de arte", uma vez que a "ocupação com o humano da obra é, em princípio, incompatível com a estrita fruição estética" (GASSET, 2001, p. 27).

Em sua avaliação técnica do ensaio no teatro, o diretor, no conto de Bernardo Carvalho, está habilitado a enxergar na performance dos atores apenas aspectos de natureza estética - as tais virtualidades de que trata Gasset. Ainda que, de acordo com a leitura do diretor, o texto da peça exija do intérprete um esforço para tornar a passagem verossímil, alinhado à concepção aristotélica da mimese, é preciso considerar que a própria verossimilhança constitui, em última análise, uma convenção, artifício que confere à ficção certa aparência de referencialidade, já que não pode haver aqui um referencial verdadeiro para as ações e sentimentos de um ser imaginário. Ou, levando-se a discussão sobre as limitações da linguagem a outro patamar, a literatura não pode se referir a nada exterior a si mesma.

O ator, por sua vez, identifica no texto uma propensão ao ressalte de características formais que não se submetem a pretensões de representar um "real possível", e cuja função talvez seja, tal como no Teatro do Absurdo de que foram precursores Bertolt Brecht e Samuel Beckett, não deixar o espectador esquecer que está diante de uma peça. A reincidência nesse modo de representar constitui, para além de uma simples oposição orgulhosa ao posicionamento do diretor, a reafirmação do ator quanto ao tipo de interpretação formal que o texto da peça exige, segundo sua leitura - interpretação esta que também não renega a dimensão artificiosa da arte aqui em foco.

É possível afirmar, então, que, num primeiro momento, e embora por procedimentos de análise distintos, diretor e ator não se deixam inebriar pela visão do jardim além do vidro. Sua atenção se volta para a transparência, ora com pretensões de apagar-lhe a refração inerente à passagem da luz, dificultando ainda mais a tarefa do espectador de perceber que entre ele e o jardim há uma barreira $^{3}$, ora de imprimir ali marcas de relativa opacidade, impedindo, assim, que uma abordagem sentimental eventualmente a confunda com a realidade.

Antes de passarmos à análise da suspensão das funções crítico-interpretativas por parte do diretor e do ator, é preciso ainda resgatar a metáfora do homem que é observado enquanto agoniza, também presente no ensaio de Ortega y Gasset e já referida neste trabalho. Na narrativa de "Estão apenas ensaiando", até o instante em que a notícia trazida pelo intruso que adentra o espaço do teatro é assimilada por diretor e ator, estes ocupam, no plano ficcional, o mesmo papel desempenhado pelo pintor encarregado de retratar a cena funesta na alegoria proposta pelo filósofo. A criticidade dos personagens que lidam com o ensaio da peça não está condicionada por um pendor à passionalidade suscitado pela existência de conexões afetivas com aspectos da cena cuja representação estão buscando efetivar, e para isto concorre o fato de que, ao contrário do que sucede na situação idealizada por Gasset, não há aqui sequer um "real" do qual se mantenham intencionalmente afastados. Desvinculado de qualquer evento "factual" que Ihe sirva de

3 Ou, mais apropriadamente, aproximando simbolicamente a barreira da própria noção de quarta parede, ao mesmo tempo transparência que convida à apreciação passional do que é representado e convenção que denuncia seu caráter de artifício. 


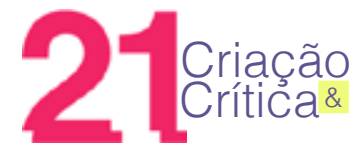

mote (ou possuindo com tal evento um vínculo que passa ao largo do conhecimento ou da sensibilidade dos personagens), o texto da peça torna ator e diretor aptos a nele captar apenas o que se funda em categorias estéticas - impede, portanto, que se compadeçam do drama encenado.

Assim, como o teor do anúncio feito pelo desconhecido atinge primeiro o diretor, é na distância guardada por este personagem em relação a uma tragédia do plano ficcional que a mudança inicialmente se opera. A notícia da morte de alguém afetivamente ligado ao ator - cujos esforços de interpretação de um homem que implora à Morte que Ihe devolva a esposa recém-falecida são coordenados pelo diretor sentado na plateia - produz no diretor a cessação imediata de sua função crítica. A sobreposição do real à representação engendra, para aquele que dirige a peça, a ilusão de que entre ambas as esferas não há fator significativo de diferenciação, como se a realidade houvesse se encarregado de prover para a ficção um referencial "a posteriori" do qual o diretor não pode, a partir de agora, prescindir ao examinar o ensaio. De fato, nem mesmo a constatação da inversão cronológica, que solapa quaisquer sugestões de que a tragédia representada haja se baseado na tragédia factual, é suficiente para que se ignore a similitude em favor da continuidade de uma avaliação esteticista. A interdição desse tipo de análise, por parte do diretor, se opera aqui devido a uma lógica análoga à evocada por Adorno, inobstante a referida descontinuidade temporal entre os contextos trágicos semelhantes, no conto de Bernardo Carvalho: ante a arte que tematiza (ou, do ponto de vista do espectador da peça, acidentalmente "passa a tematizar") um horror real, a única reação moral possível é o silêncio. Ao contrário dos artistas condenados pelo filósofo alemão, o diretor não extrai prazer estético de uma obra que, por sua vez, se nutre de uma tragédia real, mas se aproximaria deles caso prosseguisse com sua avaliação técnica da performance do ator, após o recebimento da notícia trazida pelo mensageiro. Alcançando, de modo absolutamente incidental ${ }^{4}$ e à revelia do artista-vidraceiro, sua máxima pureza, o vidro entre espectador e jardim como que desaparece, fazendo com que o personagem desça um degrau na escala de afetividade que conduz ao homem que agoniza, na alegoria gassetiana.

Passemos, então, ao ator, cuja proximidade com o foco do evento trágico, como já salientado, é maior que a do diretor. É interessante notar que o personagem é levado a conhecer o teor da informação trazida pelo mensageiro não por escutá-la do palco, mas pela reação da assistente e sobretudo do diretor ao ouvir a notícia. Sua paralisia é motivada por uma intersecção com a do homem que lhe coordenava os esforços interpretativos da plateia:

E ao ver o homem que sussurra ao ouvido do diretor, e o olhar deste e de sua assistente, que pela primeira vez não o interrompem, mas permanecem a encará-lo com os olhos aterrados e arregalados (a assistente com os olhos cheios de lágrimas diante da súplica que o lavrador faz à morte) enquanto escutam o que o outro lhes diz ao ouvido [...], embora a entonação no palco tenha sido a mesma e devesse portanto, pela lógica, ser mais uma vez interrompida, o próprio ator interrompe a ação

4 A crença de que a tragédia real que se adapta à catástrofe tematizada numa narrativa ficcional tende a neutralizar a criticidade do apreciador médio desta obra encontra interessante paralelo num caso real. Em reportagem de 2008, Simon Reynolds relata que os estúdios Twentieth Century Fox tinham, em 1999, planos de adaptar para o cinema o romance Survivor, do escritor estadunidense Chuck Palahniuk. O projeto, no entanto, teria sido cancelado após os ataques terroristas às torres do World Trade Center, nos Estados Unidos, em 11 de setembro de 2001. Como, na obra de Palahniuk, o ex-participante de uma seita religiosa sequestra um avião, que ele planeja derrubar após narrar sua vida para a caixa-preta, de modo em partes similar ao que ocorreu no contexto dos atentados reais, é bastante possível que os estúdios houvessem receado receber, por parte dos espectadores ainda comovidos com a tragédia, críticas relacionadas a oportunismo ou insensibilidade, mesmo que o livro de Palahniuk fosse anterior aos ataques. 


\section{1}

e por fim compreende aterrorizado e a um só tempo a sinistra coincidência da cena e do momento. (CARVALHO apud MORICONI, 2000, p. 595)

Convicto de que nenhum pormenor em sua interpretação do personagem que dialoga com a Morte sofreu alteração em relação aos ensaios anteriores da mesma cena, o ator deduz do fato de o diretor não Ihe ter interrompido, como das outras vezes, que algo na percepção do espectador deve ter se modificado. Esta dedução, aliada à ideia de que, para o diretor, a cena então ensaiada exigia do intérprete maior vigor para que se tornasse crível ou verossímil ao espectador da peça, leva o ator à etapa final de sua epifania: a constatação de que a notícia fez com que ele "se tornasse" o personagem, a única maneira de a mesma performance ter-lhe rendido reações distintas por parte do diretor.

Para além do evidente choque provocado pela descoberta, é preciso analisar em que medida a incapacidade do ator de prosseguir com a atuação no palco advém de uma interdição técnica relacionada à anulação das condições que tornavam possível seu discurso crítico. Retomemos, pois, um trecho do conto:

[...] [o ator] compreende que por um instante encarnou de fato o lavrador, que involuntária e inconscientemente, por uma trapaça do destino, tornou-se o próprio lavrador pelo que aquele vulto veio anunciar [...] (CARVALHO apud MORICONI, 2000, p. 595)

A inexistência de um referencial específico no plano extraficcional para os eventos encenados no palco é a principal condição para que a postura esteticista do ator, segundo o qual as falas do personagem camponês precisam ser pronunciadas com certo distanciamento emocional, se sustenha. Assim, não só a "sinistra coincidência" envolvendo as circunstâncias em que recebe a notícia da morte da esposa, bastante similares às do personagem que interpretava naquele momento, impele o ator à interrupção do ensaio, como é precisamente a imposição de um real análogo ao que se encontra tematizado no texto ficcional sobre a situação representada que elimina o pressuposto de neutralidade outrora existente entre intérprete e personagem. De volta à alegoria gassetiana, é como se, em um instante, o personagem do conto de Carvalho saltasse da condição do pintor para a da esposa do homem que agoniza - condição na qual passa a padecer das mesmas restrições de representação artística.

De forma semelhante ao que ocorre com o diretor, o ator encontra-se, após a compreensão da notícia, impossibilitado de prescindir da visão do jardim além do vidro (como Gasset supunha que fosse o ideal), visto que o incidente cria uma inesperada "impressão de correspondência" entre arte e vida, de modo que as palavras esteticamente dispostas no texto da peça parecem, por um instante, ter sua função narrativa, virtualizante, anulada, passando a exercer a de simples denotação desse lastro catastrófico que num átimo tomou lugar na realidade e usurpou do espaço teatral seu pressuposto de alheamento em relação ao mundo exterior.

\section{Repetição e esvaziamento}

É notável a ênfase com que o tema da repetição e sua concretização linguística emergem no conto de Bernardo Carvalho. Ao leitmotiv "estão apenas ensaiando", cuja primeira ocorrência se dá já no título, e às reiteradas caracterizações dos personagens e de suas ideias vêm se somar 


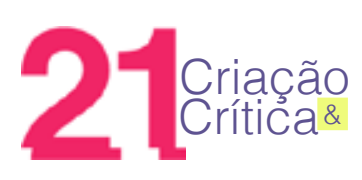

as exaustivas retomadas de um mesmo recorte cênico (com sutis variações) por parte de atores e do diretor, e da piada pelo técnico no mezanino ${ }^{5}$ - tudo ambientado no espaço do teatro, que evoca, per se, a circularidade das reencenações.

O valor estético da repetição de um mesmo mote no âmbito das artes é pontuado por Nietzsche:

Quando o mesmo motivo não é tratado de cem maneiras distintas [...], o público não aprende a ultrapassar o interesse pelo conteúdo; mas por fim ele mesmo capta e desfruta as nuances, as novas e delicadas invenções no tratamento desse motivo, ou seja, quando há muito conhece o motivo, através de numerosas elaborações, e não mais experimenta o fascínio da novidade, da curiosidade. (NIETZSCHE, 2000, p. 78)

Sob essa perspectiva, e dada a multiplicidade de indícios possíveis de que a narrativa de "Estão apenas ensaiando" se alicerce em torno da noção da suscetibilidade ética como elemento inibidor dos mecanismos de apreciação estética, supõe-se lícito tomar as repetições estruturais e temáticas do conto como artifícios que conduzam ao esvaziamento de sentido dos signos, que se reduzem, assim - como as falas de um ator que reencena a mesma peça por infindáveis noites; como a ladainha religiosa -, à dimensão de puros significantes, virtualidades dissociadas de quaisquer referentes exteriores à própria linguagem. Ademais, as imposições de extensão do conto como narrativa ficcional curta tenderiam a amplificar o efeito desse esvaziamento, já que não facultam ao leitor um "espaço hábil" para que as sucessivas retomadas se diluam ao longo da leitura, de modo a sabotar o estranhamento a elas relacionado.

Perniola (2000) recupera de Kierkegaard a ideia de uma repetição que não engendra o mesmo, mas o novo, ou "diferente":

Repetição, portanto, não quer dizer de modo algum reiteração do idêntico. Em Kierkegaard, a repetição desempenha a mesma função que a "mediação" na filosofia de Hegel: se a novidade se apresentasse no seu espontâneo imediatismo, seria imóvel ou indeterminada. Pode-se alcançar uma novidade efetiva só através do caminho indireto da repetição. (PERNIOLA, 2000, p. 30)

Trata-se de noção similar à que Manuel de Barros (2006, p. 11) manifestará pela via poética: "Repetir, repetir até ficar diferente / Repetir é um dom do estilo". Não se repete, pois, para performar novamente, mas para atingir, seja no espaço entre o dito e o subsequente redito, seja no conjunto dos reditos que se observa em retrospecto, o novo, de modo que do movimento dialético entre dito e redito assome, de fato, o inédito - aqui representado por um modelo distinto de apreciação do objeto artístico.

Dessa forma, seria possível tomar a constante que é a presença da repetição na tessitura temático-linguística de "Estão apenas ensaiando" como um mecanismo que vise à educação dos sentidos para a captação do que de fato deveria ser posto em relevo, ao considerar-se a obra de

5 Seria necessário um estudo à parte para a análise das implicações estéticas da presença reiterada da piada (a cujo conteúdo, ao contrário do que ocorre com o texto da peça, não temos acesso) na narrativa, bem como do fato de o discurso cômico ser o único que realmente se concretiza, sem perda de efeitos, ao final do conto. Esse exame poderia passar pelas distinções qualitativas que historicamente se fez acerca dos gêneros cômico e trágico, e que, em grande medida, persistem até nossos dias. 


\section{1}

arte - não as paixões, não o compadecimento pelo destino de personagens que são, em si mesmos, nulidades ontológicas, mas a própria linguagem de que se constituem essas abstrações e para a qual elas inevitavelmente convergem.

\section{Considerações finais}

Relacionar-se com a escrita de ficção como com uma dimensão outra do real, avaliála com base no nível de correspondência entre o que nela se retrata e o mundo empírico, no quão reativos seus personagens e os dramas por eles vivenciados nos tornam equivale a supor que a maravilha de um truque de mágica possa estar não na engenhosidade técnica através da qual nossos sentidos são ludibriados, mas na ideia de que, por um instante, as leis da física foram de fato suspensas e uma pessoa levitou ou dois corpos ocuparam o mesmo lugar a um só tempo.

Para Ducrot e Todorov (apud BRAITH, 1987, p. 10), "uma leitura ingênua dos livros de ficção confunde personagens e pessoas". Ao tematizar um ensaio teatral no qual visões diferentes sobre o objeto artístico são postas em confronto, inserindo nesse espaço de discussão teórica um elemento que torna difusas as linhas que delimitam os domínios do real e do virtual e posteriormente impondo sobre a arte retratada um evento catastrófico que a ela se assemelha, de modo a vetar a manutenção daqueles discursos estetizantes, o conto de Bernardo Carvalho evoca o problema da prescindência do que é exterior à linguagem de que se compõe a obra de arte quando entre esta e o real emerge certa impressão de similaridade.

O aprofundamento em relação ao raciocínio alegórico de Ortega y Gasset e aos questionamentos ético-narrativos de Adorno e de Brecht se dá, aqui, pela evidenciação de que a ordem cronológica entre o evento e o objeto artístico que com ele guarde alguma semelhança tem pouca importância no modo como a interdição do discurso estético se manifesta. Nossa sensibilidade não costuma operar a partir de preceitos cartesianos que só a legitimem quando há obediência às noções de causa e efeito - como se, quando o apelo a esta sensibilidade provém da existência de certa matriz temática comum, estivéssemos condenados a um desvio cognitivo que nos tornasse incapazes de assimilar a diferença abissal de sentido engendrada pela transposição de uma vogal nos termos casual e causal.

Contudo, no movimento de um segundo vetor que se orienta contrariamente ao primeiro, a própria estrutura de "Estão apenas ensaiando" fornece coordenadas linguísticas e motes gerais que podem auxiliar no processo de educação de nossa percepção no sentido de identificar no conto e em tudo o que nele se retrata nada além de artifício, virtualidade, quimera, o rastro deixado pelas peças de um jogo narrativo a cujo resultado eventuais reações passionais só podem ser indiferentes. As repetições de ideias, falas, frases e cenas fazem surgir, pelo embotamento gradativo do significado, o protagonismo do significante. Através da retomada de um mesmo, engendra-se paradoxalmente um outro, o diferente, essa forma ainda hoje pouco usual de encarar a obra de arte - e que pode constituir em si mesma um antídoto para a persistência da crença no objeto artístico como desprovido de autonomia, simples apêndice do real, e portanto sujeito às mesmas restrições éticas que no real se fazem necessárias.

\section{Referências}

BARROS, M. de. O livro das ignorãças, 12. ed., Rio de Janeiro, Record, 2006.

BRAITH, B. A personagem. 3. ed. São Paulo: Ática, 1987. 


\section{1}

CARVALHO, B. "Estão apenas ensaiando". In: ADORNO, T. W.; DE ALMEIDA, J. M. Indústria cultural e sociedade. São Paulo: Paz e Terra, 2002.

COMPAGNON, A. O demônio da teoria. Belo Horizonte: UFMG, 2001.

HJELMSLEV, L. Prolegômenos a uma teoria da linguagem São Paulo: Perspectiva, 2006.

ISER, W. "Os atos de fingir ou o que é fictício no texto ficcional". In: Teoria da literatura em suas fontes, v. 2, p. 955-987, 2002.

MOISÉS, M. Dicionário de termos literários. Editora Cultrix, 2013.

MORICONI, Í. Os cem melhores contos brasileiros do século. Objetiva, 2000.

NIETZSCHE, F. Humano, demasiado Humano: um livro para espíritos livres. Trad. Paulo César de Souza. São Paulo: Companhia das Letras, 2000.

ORTEGA Y GASSET, J. A desumanização da arte. Trad. Ricardo Araújo, v. 5, 2001.

PERNIOLA, M. Pensando o ritual: sexualidade, morte, mundo. Trad. Maria do Rosário Toschi. São Paulo: Studio Nobel, 2000.

PIGLIA, R. "Notas de um diário". Folha de São Paulo, trad. Paulo Werneck. São Paulo, jan. 2011. Disponível em: <http://www1.folha.uol.com.br/fsp/ilustrissima/il0901201107.htm>. Acesso em: 12 mar. 2017.

PLATÃO. "A república”. In: A República. 2000.

REYNOLDS, S. "Lawrence circles Palahniuk's 'Survivor'”. Digital Spy Magazine. London, ago. 2008. Disponível em: <http://www.digitalspy.com/movies/news/a123069/lawrence-circlespalahniuks-survivor/>. Acesso em: 17 abr. 2017.

RICHARDSON, A. The ethical limitations of Holocaust literary representation. ESharp, v. 5, 2005. WOOD, J. Como funciona a ficção. Trad. Denise Bottman. São Paulo: Cosac Naify, 2011.

\section{Recebido em: 29/04/2018 Aceito em: 18/08/2018}

Referência eletrônica: SILVA, Márcio Felipe da; PEREIRA, Vinícius Carvalho. Arte, tragédia e interdição da criticidade. O confronto entre ética e estética em "Estão apenas ensaiando", de Bernardo Carvalho. Criação \& Crítica, n. 21, p.91-105, nov. 2018. Disponível em: <http:// revistas.usp.br/criacaoecritica>. Acesso em: dd mmm. aaaa. 